\title{
Gaining Nationhood: A Comparative Analysis of Images Found in Ontario and Quebec History Textbooks, 1920 to 1948
}

\author{
Rose Fine-Meyer \\ OISE/University of Toronto \\ Catherine Duquette \\ Université du Québec à Chicoutimi
}

\section{ABSTRACT}

The centenary of the beginning of the First World War has seen renewed global attention to the war. A proliferation of scholarly works, commemorative public events, documentaries, and museum exhibits dedicated to the war ensured that the participating nations reaffirmed messages of service and sacrifice. The global response provides some insight into how nations crafted the memory of the war and the links made between remembrance and national identity. The Canadian War Museum, along with various state commemorations, encased the events of the war within narratives of heroism and sacrifice, most recently with the celebratory focus on the Battle of Vimy Ridge. This renewed interest in the war inspired this study, which explores how the war was portrayed in Ontario and Quebec history textbooks in the immediate postwar decades. This project argues that an analysis of both the textual narratives and the visual culture portrayed in history textbooks helps us better understand messages of nationhood in Canada. Through an examination of history textbooks that were approved in Ontario and Quebec between 1920 and 1948, we seek to uncover what the the Ontario Department of Education, the Catholic church, and publishers felt were important for students in schools to remember about Canada's participation in the war.

\section{RÉSUMÉ}

Le centenaire du début de la Première Guerre mondiale a contribué à renouveler l'intérêt du public pour la Grande Guerre. On observe alors une prolifération des ouvrages académiques, des événements commémoratifs publics, des documentaires et des expositions muséales qui y sont dédiés et dont le but est de réaffirmer le message de service et de sacrifice des États qui y ont pris part. Ces ouvrages et événements donnent un aperçu de comment les nations construisent leur mémoire de la guerre ainsi que des liens tissés entre le devoir de mémoire et l'identité nationale. Le Musée canadien de la guerre, ainsi que plusieurs commémorations gouvernementales, synthétisent les événements de la Grande Guerre dans un récit d'héroïsme et de sacrifice. Un exemple récent de cela est l'intérêt porté à la bataille de la crête de Vimy. Cet 
intérêt renouvelé envers la Grande Guerre a inspiré cette étude qui explore comment celle-ci a été représentée dans les manuels scolaires de l'Ontario et du Québec dans les décennies suivants la fin de la Première Guerre mondiale. Ce projet propose qu'une analyse des manuels centrés sur les récits textuels et de la culture visuelle aide à mieux comprendre les messages associés à la construction de la nation canadienne. À partir d'un examen des manuels scolaires approuvés pour l'Ontario et ceux disponibles pour le Québec entre les années 1920 et 1948, nous cherchons à découvrir ce que le Département de l'Éducation de l'Ontario, l'Église Catholique et les maisons d'éditions considéraient comme étant importants à ce souvenir à propos de la participation du Canada à la Première Guerre mondiale.

Key words: commemoration, First World War, textbooks, Quebec and Ontario, visual culture, nationhood

The centenary of the First World War — the "Great War" — has been marked globally by an increase in scholarship, commemorative public events, documentaries about the war, and museum exhibits dedicated to it. Joan Beaumont suggests these events are part of a larger "memory boom" shaped by nations who "have been turning to the past, seeking a means of investing today's social structures and values with meaning and significance." Beaumont adds, "Memory was - and continues to be - a dynamic, interactive and often contested dialogue between the state and its citizens." ${ }^{2}$ Out of a population of less than eight million, over 600,000 men and women served in the Canadian armed forces; of these, 60,000 were killed and almost 200,000 were wounded. ${ }^{3}$ The memory narrative of the First World War has been explored by a number of Canadian scholars, including Jonathan Vance, Margaret MacMillan, JeanPierre Gagnon, Tim Cook, Mourad Djebabla-Brun, Desmond Morton, Ian McKay and Jamie Swift, and James Wood, to name a few, who have noted that military conflict in general has been a central preoccupation of commemorators. ${ }^{4}$ In recognition of the centenary, the Canadian Historical Review prepared two special features to highlight past and current thinking about the war and its place in Canadian history, while the Bulletin d'histoire politique published a thematic edition on the implications of Quebec's experience in the war. ${ }^{5}$

The focus on commemoration was evident in the immediate decades after the war as Canadian citizens were exposed to forms of remembering within their own communities through government-funded commemorative plaques, stained glass windows, and monuments that could be found in public spaces, churches, and schools. Jonathan Vance has examined the commemorative discourse about the war in the post-war decades. He argues that "those four years had to have been of some use" since the war needed to be remembered to have produced "positive outcomes." In other words, mythical commemorative images of the war allowed Canadians to "fashion a usable past" out of the Great War. ${ }^{7}$ Although the use of patriotic symbols and images have since the nineteenth century found a place in public spaces and especially in schools, where students sing songs and memorialize specific historical events, the events of the First World War provided particularly fertile ground for nationalist state messages. In the post-war period, the Great War provided an opportunity to craft a broader image of a strong, independent Canada - a "nation transformed," as argued by school textbook writers — or as Duncan McArthur argues in his 1927 
history textbook, "the war represents the greatest effort that the Canadian people had yet to put forth; it marked their coming of age as a nation, with new powers and with fresh responsibilities."

Images played an important role in remembering the war. In Pearl James' edited collection, Picture This: World War I Posters and Visual Culture, scholars explore First World War posters and the ties between visual culture and the war. They analyze how poster images "nationalized, mobilized, and modernized civilian populations" to inspire united support for the war. They argue that the images portrayed in the posters "functioned as illustrations of the war in popular understandings," as well as serving as a "favoured propaganda medium of the war." Clearly, visual representations played an important role in garnering public support during the war, but what was their role after the war? And what impact did images of the war have on students in schools? This paper argues that images, important in the war period to influence public perceptions about the war, continued to play a role in history textbooks after the war and acted as a form of commemoration. It also argues that the representation of the war in textbooks was different in Quebec and in Ontario.

As Penney Clark has argued, "there is a story to be told in school history texts and in telling that story, choices need to be made, as to what is to be included, and what is to be excluded." 10 This is true for the Ontario and Quebec history textbooks explored in this study. Choices were made on how to position the history of the First World War for students in schools, and the kinds of narratives and images that were chosen for the textbook pages. The narrative in Ontario concentrated on the success of the war, the contributions of the military, and the country's shift from a colony to an independent nation. In Quebec, the message was one of duty to the state, accomplished in the midst of internal political turmoil. In both provinces, there was the acknowledgement that the war had brought a form of international recognition.

Canadian historians who focus on cross-provincial comparative studies do so in order to shed light on commonalities and differences. This study explores two regional perspectives on the First World War through an examination of approved history textbooks published in Ontario and Quebec and used in schools during the period between 1920 and 1948. It seeks to provide evidence of the notion of a national narrative. In the post-war world, these textbook narratives and images of nationhood were meant to instil a sense of pride in Canada's youth in what George Tomkins calls "an era of nationalism." 11 We sought to discover whether textbooks in both provinces served as a basis for teaching similar concepts of nationhood.

\section{Visual Culture and Historical Analysis}

In the context of North America, there has been a small but significant scholarship regarding visual culture. ${ }^{12}$ Avril M. C. Maddrell found that illustrations and pictures in historical textbooks were helpful for demonstrating an "encapsulated message." Maddrell suggests that textbook illustrations might be analyzed for messages that are not so obvious in the narrative. ${ }^{13}$ Walter Werner agrees, noting that history textbooks contain images that provide important narratives in understanding the past. 
He argues that visual images "need to be actively 'read" and that part of the task of history studies, "is to strengthen student agency to read imagery in multiple ways." ${ }^{14}$ Douglas Kellner similarly argued that reading visual media critically "involves learning the skills of deconstruction, of how cultural texts work, how they signify and produce meaning, [and] how they influence and shape their readers." ${ }^{15}$ Marie-Claude Larouche proposes different methods, allowing a critical analysis of different iconographic material such as paintings, caricatures, and photographs. ${ }^{16}$

In their study of the role of patriotic symbols in American textbooks, Eugene Provenzo and his colleagues argue that the iconographic contents of textbooks "are part of the evolution of symbols and metaphors that define a culture." In his work exploring the frontispieces of various texts, Provenzo concluded that the books "can be seen as an example of the development of a complex cultural language - of metaphors and symbols that were part of an emerging culture and its educational system." ${ }^{17}$ He traces how early texts included images of British monarchs that were then replaced by patriotic American figures such as Benjamin Franklin and George Washington - symbols altered to reflect changing symbols of the American nation.

The implications of the content of the textbooks as a source in understanding the learning of history is well established. ${ }^{18}$ Ken Osborne argues that since W. H. P. Clement's History of the Dominion of Canada was published in 1898, textbooks have contained Canadian national stories, "establishing a nation building narrative until the 1960s." 19 This acknowledges a key purpose of post-war history textbooks, to provide a basis for history teaching and curricula, but also to act as a vehicle for concepts of nationhood and citizenship.

Pearl James argues in her study on First World War posters that the war was a very visual one, documented in daily newspapers and "with modern technologies" of photography and film. "Posters were widely distributed" not just on "billboards but also in shop windows, banks, schools, churches, factories, libraries, town halls" and in numerous public spaces. ${ }^{20}$ She states that images played a major part in maintaining support for the war and allowed citizens to experience the war through the images. Jay Winter argues that "what people saw affected them more than what they read." 21 He adds that the images provided an important link between the war and the home front and became "visual codes of solidarity."22

This was evident in the Illustrated War News, a magazine published regularly throughout the war that informed Canadians about the events of the war. It was filled with images, and the images provided readers with a first-person lens into the war. Soldiers were busy maintaining trenches, railroads, and "unloading shells," "feeding shells" into guns, "bringing down" German artillery, and walking through mud-filled battlefields with horses, equipment, and the wounded. ${ }^{23}$ The significant number of photographs from the war, often full-page photos, presented in a forty-four-page magazine, would have provided the Canadian public with a strong visual image of the war. Black and white images, many of them reproductions of paintings or photographs, appeared in the news, in public, and in schools. In the post-war period, these same images of the war's destruction continued to appear in the press. Jonathan Vance argues that "photographs of ruined Belgian and French cities were common in 
post-war illustrated volumes, including some published by the government." ${ }^{24}$

In Militia Myths, James Wood argues that war narratives and images focused on the concept of the "citizen soldier" - militia drawn from civilian society, which allowed for links between the military and the home front. He argues that when the war broke out, the citizen soldier concept was reinforced in magazines such as the Illustrated News, which helped make ties to discipline and citizenship, and helped to frame the war and the subsequent memory of the war. ${ }^{25}$

The narratives found in history textbooks focused on both citizens and soldiers "doing [their] bit," and were often accompanied by images that linked citizenship and duty. We see this displayed in public images, but we also see this within textbooks. In Ontario, for example, black and white non-combat photos are presented along with reprints of paintings that reflect Canadian achievements in the war. In Quebec, images of war were available in print through newspapers and were also found in textbooks, often shown with important figures from the war, such as Marechal Foch, or soldiers in action. In Quebec, patriotic and citizenship messages were controversial due to the conscription crisis and were thus avoided in the immediate post-war period. ${ }^{26}$

Common photos in the history textbooks from both provinces in the decades following the war suggest that the textbook authors and publishers were careful to maintain a specific war narrative. In Ontario, the narrative focused on the success of the war in shaping Canada's independence. For example, in Canada-A Nation: And How it Came to Be (1948), Lower and Chafe state "when Canada entered the war she was still barely beyond the colonial stage of development: when she emerged from it, she was almost an independent state." 27 Below this statement is a photograph of the National Memorial, dedicated "to those who died in the First World War" - a twenty-one-metre (seventy-foot) granite pedestal and arch adorned with a Greek goddess and twenty-three bronze figures. A similar message is found in Quebec in l'Abbé Adélard Desrosiers' 1933 Petite histoire du Canada, where it states that the political result of the war was Canada receiving a place in the League of Nations (Société des Nations). However, Desrosiers nuances his text, since he concludes that the war caused multiple deaths and was disastrous for the economy of the country. ${ }^{28}$ The conclusion is supported with an image of a humanized representation of France mourning the dead Canadian soldiers. [See figure1.] It seems that in Desrosiers' Petite histoire $d u$ Canada, gaining political independence was not sufficient to cover the loss of so many young Québecois men.

Pearl James contends that First World War posters were more than mere propaganda; they were a "favoured propaganda medium of the war," weapons to seek public support for the war. ${ }^{29}$ This study suggests that the visual images and narratives found in history textbooks in the immediate post-war decades were also forms of subtle propaganda. They did little to reflect the stark reality of the war, but were carefully crafted and placed within textbooks to seek collective support for the war and to ensure that the memory of the war was mostly positive.

Although this study explores textbooks, it does not examine teacher pedagogy or demonstrate how the textbooks were used in classrooms. It also does not document 


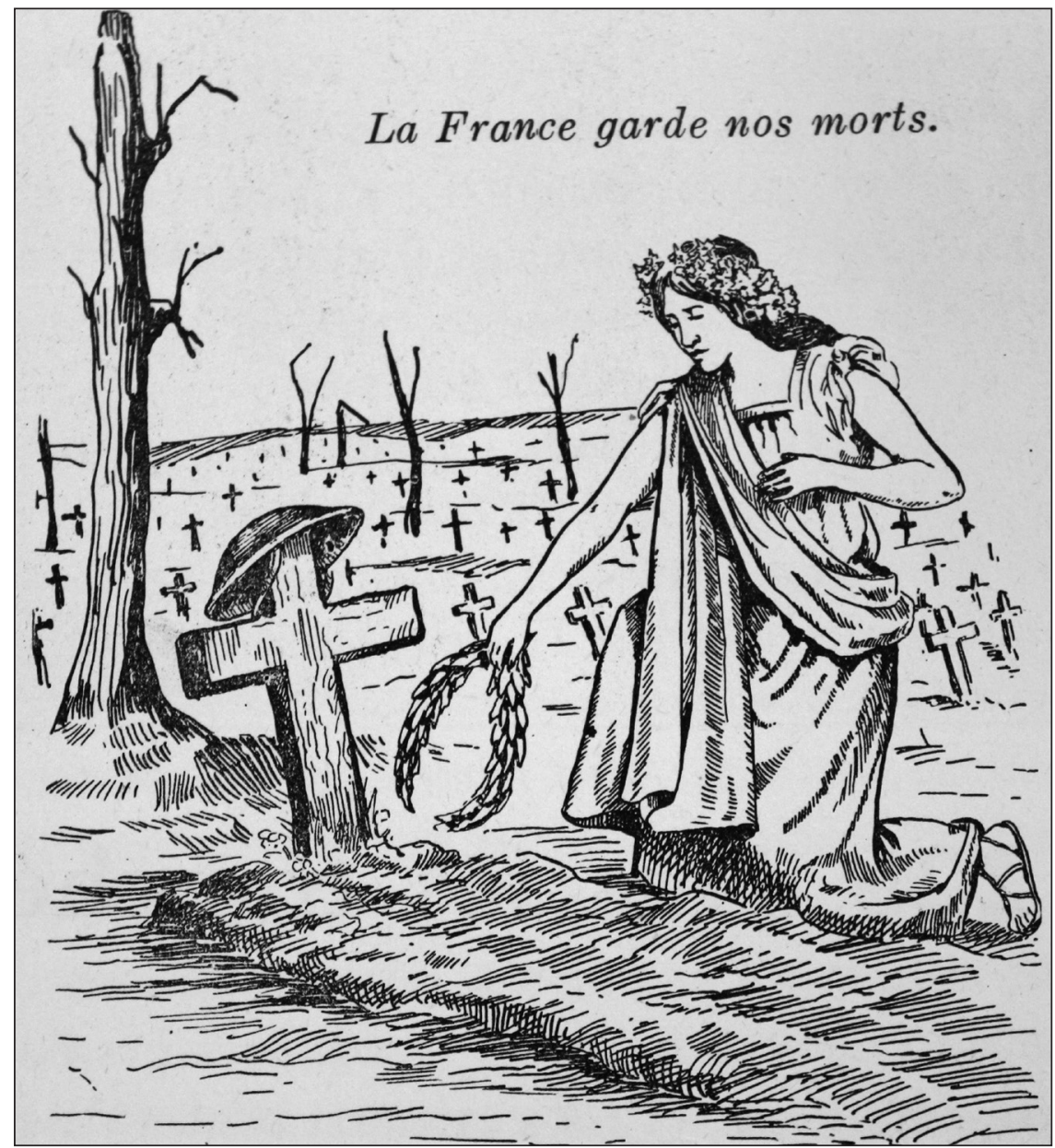

Figure 1: La France garde nos morts. Geo-Henri Duquet for Abbé Adélard Desrosiers, Petite histoire du Canada (Québec : Librairie Garneau, 1933), 174.

the impact the images or the textual narratives had on students during that time. Instead, it wishes to observe whether the iconographic material provided in textbooks told a different narrative than the text did. Its second objective is to compare the perspectives of two provinces on the historical significance of the war.

\section{Literature Review: Textbook Historiography}

There is rich scholarship on the history of textbooks in the Canadian context. George Tomkins notes that E. T. White's 1922 study of textbooks in Ontario "revealed that regulations governing textbooks were basically similar in most provinces." ${ }^{30} \mathrm{He}$ argues that use of unauthorized textbooks meant that teachers could be 
suspended and funds to school boards withheld. So textbooks became standardized across the country, with Ontario textbooks appearing in other provinces. Publishers catered to the Ontario market because it had the largest English-speaking population. Ontario established a textbook office in 1912 that existed until $1956 .{ }^{31}$ In Quebec, the French school system was managed by the Catholic church until 1964, when the Ministry of Education was created. Before then, clerical groups wrote and edited diverse textbooks, with some groups specializing in specific disciplines, such as Les Frères des Écoles chrétiennes for history and the Frères Maristes for geography. ${ }^{32}$ In 1880, a debate arose between the government, which wanted to impose a unique textbook for each discipline in order to harmonize the education received in schools, and clerical and ultramontanist groups, who were opposed to any law that diminished their influence on the school system. This debate was not resolved until 1944 when school boards were allowed to choose which textbooks were to be used in their schools. ${ }^{33}$ The lack of proper guidance in textbook production might also explain the vast number of textbooks, chronologies, and exercise books published between 1915 and 1940 in Quebec.

Penney Clark has written extensively on the history of textbook publishers in Canada and explores the political influences and commercial pressures employed in the publishing of textbooks. ${ }^{34}$ She argues that "ultimately textbooks are as much political and economic, as they are pedagogical artifacts." ${ }^{35}$ Clark's scholarship on history textbooks provides an excellent overview of the historiography of history texts and her work provides insight into textbook publishing. Clark notes the importance of textbooks, pointing out that they "enjoyed the status of de facto curriculum," since there were few other resources available for teachers in the early twentieth century. ${ }^{36}$ Clark adds that in Ontario between 1885 and 1907 three prominent Toronto publishers dominated the textbook market. Quebec textbooks were mostly produced by members of the clergy and published by both lay and religious editors. Both l'Abbé Desrosiers' Petite histoire du Canada and Rutché and Forget's Précis d'histoire du Canada; pour les élèves des classes supérieures de l'enseignement secondaire were published by Librairie Beauchemin, situated in Montreal, a company which served as an important publisher, selling books across Canada and the United States. ${ }^{37}$ The other textbooks were published by religious organizations such as $\mathrm{La}$ librarie de Clercs de St-Viateur and La librarie du Sacré-Cour, which were both heavily involved in the school system.

George Parker explores the changing role of publishers during the war. The competition for the sale of textbooks was fierce, as publishers sent agents across the country to show off their books. Parker writes, "Along with other commercial travellers, book salesmen crossed Canada by rail, laden with sample trunks of new books, dummies, and sheets, together with lines of stationery and cards, and new textbooks for provincial education officials." ${ }^{8} 8$ So profitable was the sale of textbooks that the number of publishing companies expanded in the first decades of the twentieth century. New companies such as Macmillan, Thomas Nelson, and McClelland \& Goodchild joined venerable firms such as Copp Clark, W. J. Gage, and the Methodist Book and Pubishing House. 
A study by Marcel Trudel and Geneviève Jain commissioned by the Royal Commission on Bilingualism and Biculturalism in Canada in 1970 found that there were clear differences between English and French textbook presentations of Canadian history. The commission was particularly interested in themes of nationalism and the ways textbooks reflected relations between English and French cultures. Textbooks, they argued, formed the basis of student learning, since many students did not acquire post-secondary education. They defined how the majority of students were educated in Canadian history. Trudel and Jain found that texts portrayed the role that government and industry played in shaping Canadian history, providing a basis for definitions of good citizenship. ${ }^{39}$ The history textbooks examined in this paper also reflect themes of nationalism. The war chapters provide consistent frameworks, with common images shared among different publishers. War commemoration plays an important role in their particular inclusion and placement within the text.

History textbooks in Ontario focused on the narratives of predominantly white industrial and military men and Canadian constitutional and political history. In the early years of schooling in Ontario, textbooks were taken from lists in Britain. History textbooks, originally written by British and then prominent Canadian historians, such as W. L. Grant, George Wrong, or W.M. Stewart Wallace, provided documented historical narratives. Their main objective, to "foster ideals of citizenship," was central to their design. Between 1922 and 1948 six Canadian history textbooks for secondary school students were approved for use in Ontario schools. The low number of textbooks was the result of a number of factors, including the high cost of publishing. Replacing textbooks was expensive, and subject areas competed in each school for limited funds; therefore textbooks remained in school systems beyond changes to the curriculum. All Ontario-approved textbooks were included on the ministry's Circular 14 lists. ${ }^{40}$ Outdated books remained on the approved list as new textbooks were introduced, recognizing that when the curriculum changed, all schools were not in a position to replace their textbooks; teachers were expected to adapt old textbooks to new curricula.

George Tomkins suggests that progressive ideas in education had a limited impact in the first half of the twentieth century because of "ingrained conservatism," and the presence of mandatory provincial exams. Schoolwork was routine and focused on memorization and frequent testing. In both Ontario and Quebec, there were annual provincial exams. Robert Stamp notes that in the post-war period Canadian high schools contained a growing student body with "a wider range of social class and achievement level backgrounds." ${ }^{11}$ Post-war youth was of concern to authorities in the decades following the war. Stamp states that discussions across the country related to how schools should respond, either through changes to curriculum or changes to extracurricular activities. ${ }^{42}$ A number of programs in schools were designed to support the development of good citizenship and the subject of history provided a venue. H. J. Cody, Ontario's minister of education in 1918, noted that history education was "the great vehicle of patriotic instruction" in a curriculum that remained, in English-speaking Canada, "politically conservative," and focused on Anglo-Saxon male achievements with imperial ties. ${ }^{43}$ Publishers were aware of reforms to the 
curriculum in order to have their textbooks approved by the state.

In contrast to Ontario, Quebec's school system was not administered by the state until 1964. Before that date, as Bouvier and his colleagues point out, the educational system was under the strict jurisdiction of the Catholic church. ${ }^{44}$ The church was opposed to mandatory schooling because children were seen as an essential part of the rural workforce. There were also tensions within the institution of the church regarding the possibility of higher education. Les frères des écoles, such as the Clercs de St-Viateur created what was called le primaire supérieur, which allowed students to gain access to an undergraduate degree. ${ }^{45}$ This effort to expand the school system was not well received by church leaders, who wanted to limit access to university to those students having completed what was called "Le cours classique." This had an impact on this study, for the majority of Quebec textbooks were written by priests or clerics and not by local historians or teachers. Textbooks had to be approved by the Comité catholique du Conseil de l'instruction publique de la province de Québec before being distributed in the classrooms. Thus, in contrast to Ontario, textbooks in Quebec did not reflect the state narrative, but rather the narrative selected by the Catholic church. Similarly to Ontario, however, Quebec textbooks published between 1910 and 1940 enjoyed a long life, since they were often reissued from one decade to the next. For example, there were five new editions of the Rutché and Forget textbook, Précis d'histoire du Canada; pour les élèves des classes supérieures de l'enseignement secondaire, published over the course of twenty years (in 1924, 1928, 1932, 1937, and 1945).

By the 1940s, the number of publications had decreased, with only four textbooks remaining: Farlay and Lamarche, Histoire du Canada; cours supérieur, Forget and Rutché, Précis d'histoire du Canada; one by the Frères des écoles chrétiennes, Histoire du Canada; and one by the Frères du Sacré-Coeur, L'histoire du Canada. As in Ontario, it is probable that the costs associated with the creation of a textbook and the context of the Second World War explain this situation, but the particular context of education in Quebec at the time might also provide interesting insight into their continual usage. Being administered by the Catholic church, the educational system underwent little or no change before the publication of the Parent Rapport in 1962. Since curricular demands remained similar, history textbooks continued to be current and didn't need many modifications. Indeed, comparing different editions, we noticed that authors changed very little, adding sometimes a section on recent events. For example, in Rutché and Forget's Précis d'histoire du Canada, additions are small, such as specifying the date of King George V's death. Apart from this example, the narrative dealing with the First World War remained for the most part unaltered.

The Catholic church in Quebec, at least the upper clergy, had historically encouraged and supported allied policies during the war and, to a certain degree, conscription. ${ }^{46}$ For example, during the riots against conscription in 1918, Bishop LouisNazaire Bégin ordered all the priests in his diocese to read a pastoral letter during mass that ordered the people to respect law and order. They saw the riots as being opposed to Christian principles, and the church was completely against them. ${ }^{47}$ From the perspective of commemoration, it can be argued that Quebec's textbooks at that 
time illustrate the memory of the war that the upper clergy of the Catholic church wished to pass on to the population. The corpus for Quebec can be divided into three categories: textbooks, which included a narrative and illustrations of the events of the First World War; chronologies, which were lists of dates and the associated events; and question books that contained questions or exercises to be completed by students using information found in the texts. Recently in Quebec, particularly in the scholarship of Djebabla and Mesli, it has been argued that Quebec's textbooks proposed a more consensual view of the First World War. However, this position does not take into account the iconographical elements found in the textbooks, nor supplementary teaching material, such as chronologies or question books. ${ }^{48}$ This study suggests that all components of a textbook have their importance in the overall aim of teaching students a specific historical narrative. Illustrations are particularly significant, as there are so few of them in the post-war textbooks.

\section{A Thematical Analysis that Draws on Textbook Observations}

The following exploration of textbook themes is a result of this study's findings and reflects some of the common narratives and images found in the texts. The five themes we explore include generals and warfare, soldiers, the home front, conscription, and nation-building.

A few things are clear: textbooks have a clear narrative framework for the war, featuring particular events and interpretations and avoiding others. The 1920s was a period of renewed nationalism and this can be viewed in the textbook themes. In Ontario and Québec, there is clear celebration of the war as a catalyst to independence from Great Britain. During the war, for example, the Ontario provincial government directed all schools to add "the war, its causes, and the interests at stake" to their history courses, ${ }^{49}$ supplemented by pamphlets such as "The Children's Story of the War." ${ }^{50}$ Children in both provinces were active in a number of fundraising initiatives to support the war effort.

\section{On Generals and Warfare}

In Quebec textbooks, only Archand's Histoire générale de l'église d'après le nouveau programme included illustrations that pictured events of the war, which supports the European focus of his narrative. Among the images, there is one showing the event that is believed to have started the war, the assassination of Archduke Franz Ferdinand, and one showing the event that "ended" the war, the German armistice. If other textbooks seem to agree that the assassination of Archduke Franz Ferdinand was the starting point for the First World War, they also tend to specify quite clearly that Prussia was guilty of greed and that the war was the fault of the entire country and its leader: "L'Allemagne, l'instigatrice de cette entreprise criminelle, déclara à son tour la guerre à la Russie et la France." ${ }^{1}$ The event that marks the end of the war, however, is not completely agreed upon. Archand's Histoire générale de l'église associates the surrender of the German troops with the war's final moments, while Farley and Lamarche's Histoire du Canada; cours supérieur and Desrosiers and Bertrand's 
Histoire du Canada prefer to end their narrative with the death of Laurier in 1919. His death is seen as the end of an epoch in which French Canadians had a strong voice within the federal government. The church's strong influence on textbooks can be seen here: associating Prussia with one of the deadly sins, greed. By doing this, it was made clear to students that Germany was a threat to both state and church. The war chapters end with the death of Laurier. Contrary to Djebabla and Mesli's position that the textbooks promoted a consensual view of the war, French Canadians are central to the grand narrative of the politics associated with the war. They consider the time Prime Minister Laurier was in power as one of the causes of the newly gained political autonomy of Canada. ${ }^{52}$

Apart from Laurier, there isn't a specific French Canadian military general or politician. The military is represented either by French Maréchal Foch, General Joffre, or the Van Doos (the popular name given to the 22nd French Canadian Infantry Battalion; Van Doos comes from vingt-deux), which seem to be a symbolic representation of French Canadians abroad. This choice is rather curious since FrenchCanadian war heroes were well-known to the population. ${ }^{53}$ General Tremblay, the leader of the 22 nd battalion, for example, was seen by both his troops and the public at the time as a brave and daring leader. French-Canadian soldier Jean Brillant was awarded the Victoria Cross posthumously. ${ }^{54}$ For Keeland, the absence of commemoration for specific individuals in French Canada is related to the province's desire to "forget who supported [the war]." 55

While Quebec textbooks do not mention the names of any French-Canadian generals, the English textbooks provide a list of the English-Canadian and English generals involved in the war. For example, Generals Arthur W. Currie and Julian Byng are seen leading the troops into battle in Ontario textbooks. This difference seems fundamental, for if Djebabla and Mesli note a general similarity between the narratives found in both Ontario and Quebec textbooks, the illustrations underline a very different emphasis on who should be commemorated. ${ }^{56}$ This observation is thus more in line with Vance's argument that English and French Canada did not agree on how to commemorate the First World War. ${ }^{57}$

Ontario textbooks also contain prominent images of King George V, while he is present in only one French-Canadian textbook, Rutché and Forget's Précis d'histoire $d u$ Canada, along with Prime Minister Robert Borden. Generals and political leaders are all male, all white, reproduced in black and white, and the illustrations take up a small portion of the page so that text remains the dominant focus. Links to empire between Britain and the Canadian generals are found in the images placed in texts. George M. Wrong's Ontario Public School History of Canada opens with a full-page image of King George $\mathrm{V}$ and links to Canada's role to bolster ties and position within the British Commonwealth. Wrong's war chapter contains an image of a uniformed Sir Arthur W. Currie, accompanied by the text "the gallantry and fortitude shown by Canadian soldiers," and links to empire. The text claims that Canada, as a "British nation... fought side-by side with other nations within the British Commonwealth." 58 W. L. Grant's text, Ontario High School History of Canada, begins with an image of King George with Queen Mary. The king is placed 
strategically at the beginning of the text, with General Currie placed in the war chapter, in full military uniform, leading the Canadian troops into Mons. Although this text notes that Currie was "not a professional soldier," and had "risen through sheer merit from the rank of an unknown officer the image of Currie is authoritative, and remains the same in all texts." 59

The decision to include General Currie and not General Byng is also noted in this study. Sir Julian Byng was a British commander of the Canadian corps from 1916 to 1917 and the general at Vimy Ridge, who was "loved and trusted by his troops," who called themselves the "Byng Boys." Tim Cook notes that throughout the interwar period, "Viscount Byng of Vimy was well-known across the country." ${ }^{60}$ After the victory at Vimy Ridge, Byng was elevated to command one of the British armies on the western front. Haig wanted to replace him with another British general, but Byng suggested that "it was time for a Canadian to lead." ${ }^{61}$ Cook argues that although Byng was well-known and respected, historical accounts, especially in educational materials, focused on Currie. Cook suggests that the focus away from Byng, a British general, may not have "fit[ted] into the national myth" of an all-Canadian corps that became a defining moment in "the birth of a nation" narrative. ${ }^{62}$ Currie commanded the Canadian corps from 1917 to 1919 . A militia officer, Currie had limited experience as a commander, and faced the challenges of a well-established British military elite. In choosing to feature Currie over Byng in Ontario history textbooks, it is clear that the textbook authors were demonstrating the important leadership role played by Canadians during the war. But the texts also avoid the inclusion of angry memories that many soldiers had of their officers. Desmond Morton notes, for exmple, that William Bird and W. D. B. Kerr's memoirs of the war revealed few positive memories of officers, including Currie. ${ }^{63}$

Despite the realistic and vivid images portrayed in the press and magazines such as the Illustrated War News, textbooks contained few detailed images of battles or trench warfare; these prominently featured in later textbooks. Messages of heroism, pride, and hope are more prevalent through the images of proud generals commanding their troops. Postwar textbooks do not contain images that honestly present the horrors of battle or the larger military-industrial complex that sustained the war for four long years. ${ }^{64}$

\section{Lives of Soldiers - and Trenches}

In Helen B. McCartney's study of the First World War British soldier, she notes that "for at least 50 years following the end of the First World War, multiple, diverse images of the soldier were presented in British public discourse, and that of the soldier as hero persisted strongly." ${ }^{5}$ The image and narrative of the brave and heroic soldier is also present in Canadian history textbooks, more clearly in Ontario than in Quebec.

In Quebec, information about soldiers in textbooks is not always consistent. For example, the reported number of soldiers who died during the war changes noticeably from one author to the next: Farley and Lamarche's Histoire du Canada notes that 55,000 soldiers died while in Rutché and Forget's Précis d'histoire du Canada, the reported death toll was 63,669 men. However, although the number of deaths varies, 
the soldiers are always seen in a positive light, either having the advantage during a battle or in doing their daily duty cleaning trenches. Quebec textbooks speak almost exclusively of the 22nd battalion and list the battles in which French Canadians distinguished themselves. As an exception to this, textbooks sometimes mentioned the names of Byng and Currie, but their importance is limited to their role of authority in the war. Desrosiers' Petite histoire du Canada presents an ambivalent view of the 22nd battalion: proud of the fact that the regiment never had trouble renewing itself, yet saddened by the 6,000 French-Canadian men that died in Europe. ${ }^{66}$ In Quebec, we find illustrations of French-Canadian soldiers and trench life in Archand's Histoire générale de l'église d'après le nouveau programme, Desrosiers' Petite histoire du Canada, and Desrosiers and Bertrand's Histoire du Canada. This is surprising, for the narrative that surrounds the text does not make mention of the topic. The authors only list a number of battles, French Canadians or Canadians; the varying terminology used makes it difficult to tell if authors are speaking specifically of French Canadians or of the English and French populations. The texts mainly include the battles at Courcelette, St-Eloi, and Ypres, as well as the battle at Vimy Ridge. In most cases, Vimy Ridge is not seen to be a more important battle than Courcelette or Ypres; this can be seen in the Desrosiers and Bertrand Histoire du Canada where the authors prefer to show a reproduction of a watercolour by J-Bte Lagacé titled Les Canadiens à Courcelette and not a similar painting of soldiers during the Battle of Vimy Ridge. ${ }^{67}$ [See figure 2.] It seems that, as Eric Labayle believes, the prestige associated with Vimy Ridge later might not be associated with the battle itself but more with its geographical location. ${ }^{68}$ If Quebec textbooks celebrate the bravery of the Van Doos on the battlefield, details of the battles are never provided for the reader. No maps in the textbooks show troops' positions or even illustrate the different state borders in Europe at the time. The figure of the soldier is made sufficiently vague in order to represent the French-Canadian nation as a whole. This might also be because the textbook is focused on the history of Canada instead of Europe. Thus, the battles are seen as detached from the main narrative of the country. The proof of this would be the importance given to the unionist government and the conscription crisis, both events being closer to home than the battles.

In contrast to Quebec, Ontario textbooks present soldiers facing the horrors of trench warfare, but with few or no visual images to support the text. "Canadians in Action" is often the subtitle, and narratives use descriptive language to describe soldiers in battle. Lower and Chafe's Canada-A Nation states that "the war was the most awful of ordeals. It meant living in the ground like animals for weeks at a time... It meant going over the top in the face of machine-gun fire, then, for those who survived, settling down to more weeks of filth and misery." ${ }^{99}$ The Great War chapter in the 1930 W. M. Stewart Wallace textbook, A History of the Canadian People, has few images. There is, however, an almost full-page map showing the Western Front, where the Canadians were engaged in the field. There is also a reproduction of a painting, The Canadians at Ypres, by Richard Jack, that states that "when they [soldiers] came out of the trenches there was little left of them." ${ }^{\text {" }}$ However, the text quickly adds, "the Canadians were recognized as the best troops on the western front" and later, "the war 


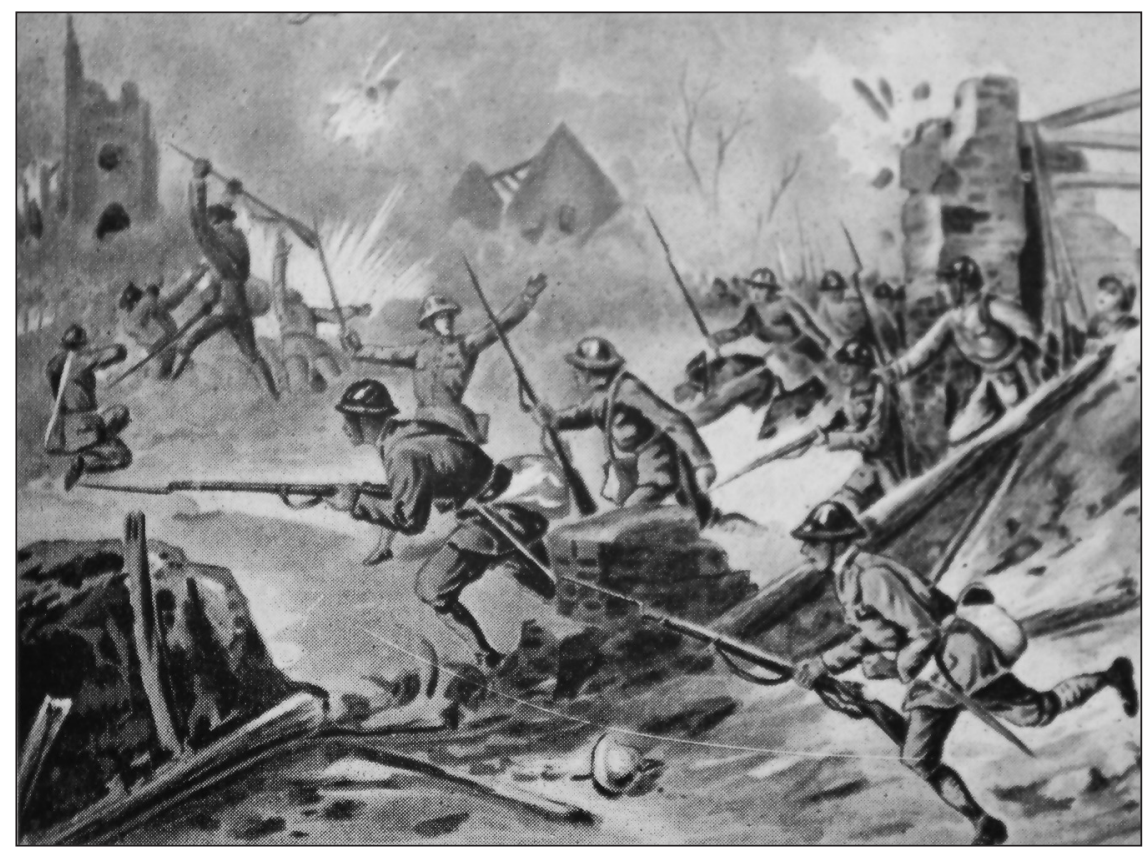

Figure 2: Les Canadiens à Courcelette, watercolour by J-Bte Lagacé, published in Abbé Adélard Desrosiers and Camille Bertrand, Histoire du Canada (Montréal: Beauchemin Éditeur, 1923, 1925, 1933), 452.

gave us a consciousness of strength which intensified our national feeling: it gave us a deep repugnance to the secret democracy which had helped on the catastrophe; yet is also bound us closer to the other members of the Imperial Commonwealth." ${ }^{\prime \prime 1}$ The text refers to the "mother country," but the images are those of Canadian-led battles and a reprint of I. Sheldon-Williams's painting of the Canadians entering Mons, with an extended text that ties together the Canadian soldiers, heroism, bravery, and nationalism. [See figure 3.] It states that "after the Armistice, the Canadians were among those chosen to cross the Rhine and occupy German territory; and the German people had the unwonted $[s i c]$ experience of hearing from the Canadian regimental bands the strains of The Maple Leaf [Forever] and O Canada." 72

The reproduction of I. Sheldon-Williams's painting is a common image in Ontario textbooks. This painting of Canadian soldiers crossing the bridge into Mons, Belgium, at the conclusion of the war, is placed towards the end of the war chapters. For Canadian soldiers, the First World War ended in Mons. This image has a similar text accompanying it - "The Canadian troops amid the ruins of Ypres, Belgium" - contained within narratives that speak to the "immense" sacrifices that "changed Canada forever." This image is important, since it represents where the war ended; the last Canadian soldier died there and its place in the Ontario textbooks is symbolic of Canada's achievement as a nation.

The W. L. Grant textbook also includes a map of the Western Front and a painting called Landing of the First Canadian Contingent at St. Nazaire, France. ${ }^{73}$ But what 


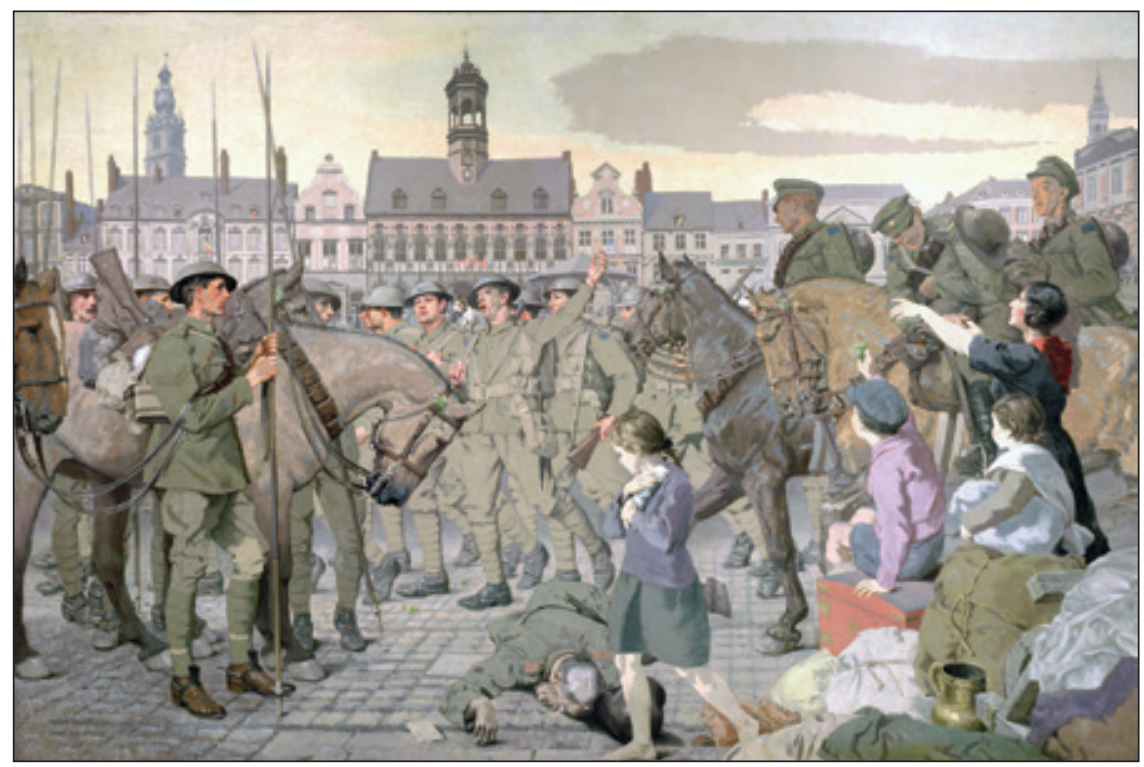

Figure 3: Painting, The Return to Mons, by I. Sheldon-Williams (1920), reproduced in W. M. Stewart Wallace, A History of the Canadian People (Toronto: Copp Clark, 1930), 328, and George Brown, Building a Canadian Nation (Toronto: J. M. Dent, 1942), 409. Courtesy of the Canadian War Museum, Beaverbrook Collection of War Art. CWM 19710261-0813.

stands out is a powerful reproduction of a Punch image showing a Canadian soldier standing in the field holding up his rifle with his right arm and a large United Kingdom flag with his left. [See figure 4.] The caption states "Canada! Ypres, April 22-24, 1915." This image perhaps demonstrates strength at a time when the Canadian divisions had suffered the impact of the Germans' release of 160 tons of chlorine gas. Like other textbooks, the chapter ends with an image of Sir A. W. Currie and the Canadians entering Mons, which supports the text, "The war ended with our troops in the historic town from which at the beginning of the war the famous retreat had begun." ${ }^{\prime 4}$ The real importance of this was the idea that Canadians had held their ground despite the gas attack. Images of heroism provide support for text narratives about the future. The image of Canadian soldiers crossing the Rhine, for example, links to the final paragraph of the book, which states: "our country has a story worthy of the great races from which we are proud to have drawn our birth, and that she may justly look forward to a future." 75

In both Ontario and Quebec textbooks, major battles are included equally. In Ontario, it seems that Ypres gets a little bit more attention, and the majority of textbooks have an image of Ypres. In Quebec, it is the Battle of Courcelette that takes precedence, and it is the only battle for which we have images. Contrary to the fact that Vimy Ridge has become central in defining Canada's experience of the war, the post-war textbooks do not feature that battle prominently. The end points of the narratives, however, are different. Ontario textbooks close chapters on war with images of the Parliament buildings in Ottawa, whereas in Quebec, most of the 


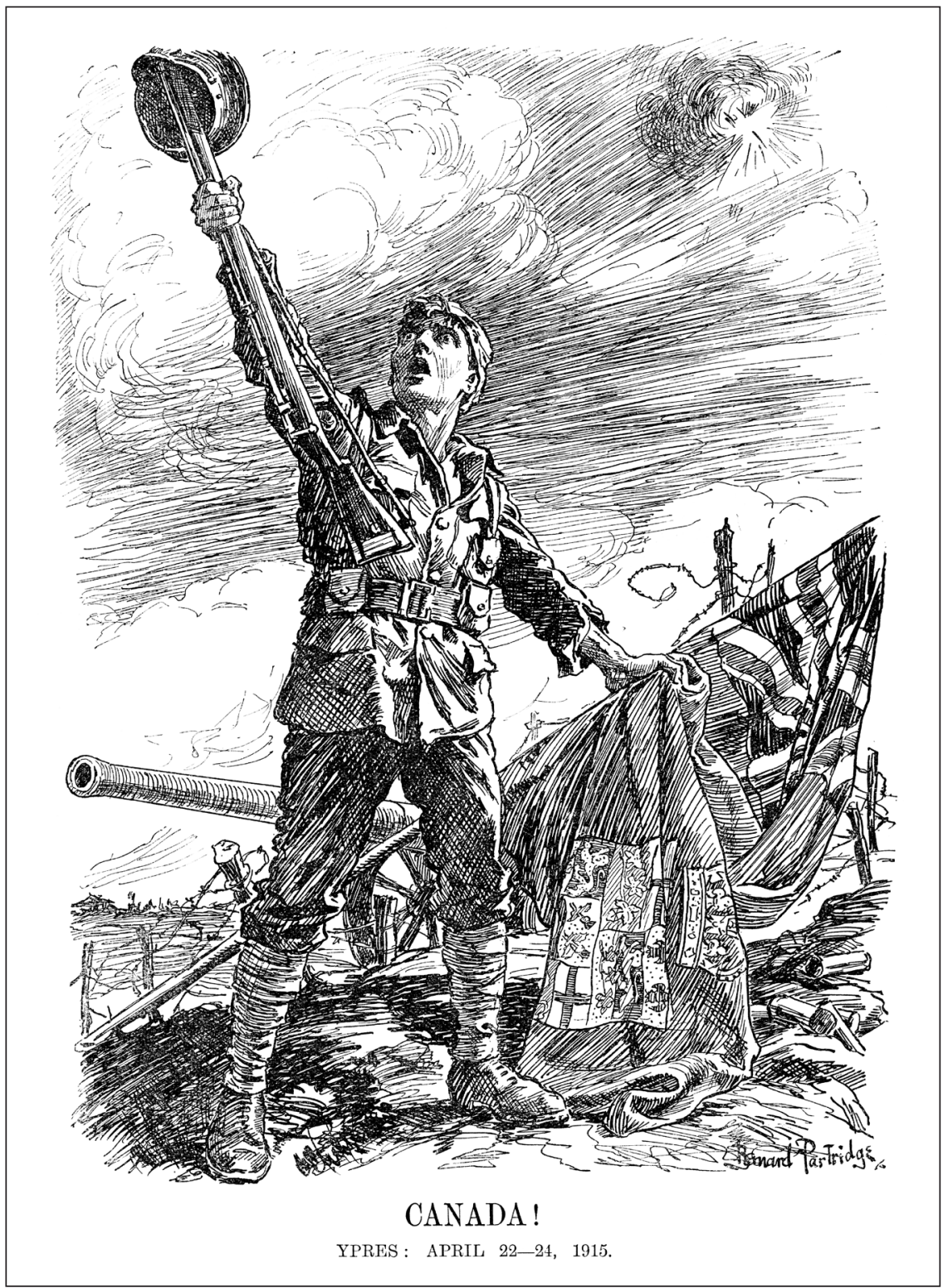

Figure 4: Bernard Partridge, Canada! Ypres: April 22-24, 1915. Courtesy of Punch, reproduced in W. L. Grant, Ontario High School History of Canada (Toronto: Ryerson Press, 1922).

textbooks close with images of Sir Wilfrid Laurier. Ontario sees the end of the war as a beginning of a more independent nation, thus the image of the government buildings, while in Quebec, the textbooks recognize its new-found independence and find a place for French Canadians in the narrative. They are, however, also aware 
that with Laurier's death, the influence of French Canadians at the federal level had diminished.

\section{Work on the Home Front}

All texts in Quebec, except Archand's Histoire générale de l'église d'après le nouveau programme, focus on events happening in Canada during the war, rather than events taking place in Europe. Archand is also the only author to provide an illustration of a military weapon, a cannon, in great detail. No images of civilian life during the war are included in the textbooks. The narrative in most textbooks is limited to the political events that happened in Canada during the course of the war. A picture of Robert Borden is included in a single textbook, Rutché and Forget's Précis d'histoire $d u$ Canada, although the Unionist government is explained in most texts. The political situation is used as a premise to the conscription crisis, a theme that will be dealt with separately here.

There are also limited images of the home front in Ontario textbooks. Prime Minister Robert Borden's image is often included, but war chapters do not focus on factory work; such images appeared later in textbooks published after 1950. Clearly the topic of Canadians' support for the war at home garnered interest, but as Wood notes, attendance at parades and public functions began to wane over time. However, when references are made to the home front in the text, they reflect images of support for the war overseas. In George Brown's Building the Canadian Nation, for example, food production and supplies for the war are explored in the text narratives, but the images include a map of the Western Front and Canadian "flying ace" and Victoria Cross recipient Billy Bishop, who is seen sitting in an airplane. The publishers also included a full page of newspaper headlines, a first for history textbooks in Ontario. Despite including the page of newspaper headlines about the Halifax explosion, strangely the event is not discussed in the narrative; rather, the headlines are part of a broader end-of-chapter discussion about the "ravages of war." ${ }^{\text {"6 }}$ Robert Price's study on Canadian newspapers during the war argues that they had an important role to play in maintaining order and ensuring mass support for the war. ${ }^{77}$ Perhaps the decision to include images of newspaper headlines of the Halifax explosion acted as a reminder of the links between the home front and the war overseas. ${ }^{78}$

Lower and Chafe's Canada-A Nation textbook, revised several times, includes one very large image of a giant arm reaching into the heart of France. The text below this Punch cartoon states, "How the Germans reached for Paris in 1914." The narrative notes that the German strategy was to: “... punch through Belgium, roll up the French armies with a movement like a great giant sweeping round his right arm, separating them from the British armies and driving these into the sea." 79 The image sends a powerful message but what follows is only a brief discussion of the Canadian people doing their best, "springing into action by enlisting and organizing the production of war supplies." 80 The image portrays the frightening power of the war, but combined with the text narrative, is perhaps suggesting that the Canadian commitment to the war effort helped prevent the Germans from winning. 


\section{Quebec and the Conscription Crisis}

The 1917 federal election revolved around the issue of conscription and this is explored in all textbooks, in different ways and at different depths. Desmond Morton argues that Borden believed that "conscription was the price Canada must pay for a new and more dignified status in the world." ${ }^{81}$ The results of the government's decision to impose conscription divided English and French Canada, and exposed long-term divergent visions for Canada. As expected, all textbooks in both provinces incorporate this debate.

When it comes to the conscription crisis, the illustrations found in Quebec textbooks published between 1920 and 1948 are in some ways puzzling. For example, a majority of textbooks speak of the conscription crisis, but none provide illustrations of the civic unrest or of Henri Bourassa, who publicly took a position opposing Borden's policy. ${ }^{82}$ Bourassa, an elected member of Quebec's provincial government, spoke against Canada's participation in the war, but he is absent from the narrative: no textbooks mention him or his opinions. The conscription crisis presented in the Quebec textbooks varies greatly from one text to the next. Rutché and Forget's Précis d'histoire du Canada deals with the crisis briefly by explaining that the government had no choice but to use conscription to attain the number of soldiers needed in Europe. Desrosiers' Petite histoire du Canada only explains what the term conscription means. Desrosiers and Bertrand's Histoire du Canada also speaks briefly of the crisis, but specifies that the Unionist government, which was widely popular in the western provinces, only elected three out of sixty-five members of Parliament in Quebec, thus stating clearly the province's position against conscription. They note that although the conscription bill was vigorously debated, it still passed. In Farley and Lamarche's Histoire du Canada, the victory of the Unionist government is linked to the soldiers' vote. They are the only authors to give the conscription crisis a full section of their book. In contrast to the other texts, the authors also clearly state that Quebec and other French-speaking Canadians were against the bill. They note that Laurier fought against it for he thought — rightly — that it might revive tensions between French and English Canadians. They aso mention that French Canadians were against conscription because they were a peaceful nation, unaccustomed to war, and more removed from Great Britain than English Canadians. They also note that the Ontario motion against French instruction (Regulation 17) in schools accelerated tensions between French and English. Finally, Archand's Histoire générale de l'église d'après le nouveau programme, which presents the most detailed explanation of the war, battles, and soldiers, does not speak of the crisis at all. Apart from Farley and Lamarche's Histoire du Canada, all textbooks focus on the conscription crisis as a federal political event. In this way, they do not have to tackle the conscription crisis, a topic condemned by the Catholic church. The message that most authors prefer to give is that conscription was a necessary evil needed to ultimately win the war. The need to avoid the controversy attached to the conscription crisis might also explain why provincial events are not dealt with in the Quebec textbooks. Writing about the provincial home front would have involved talking about Bourassa and the riots. ${ }^{83}$ Only Farley and Lamarche's textbook uses the home front to discuss the good salaries 
paid by munition factories and the importance of farm work as a cause for the lack of men joining the army, necessitating conscription. All this brings Djebabla and Mesli to argue that the message proposed by textbooks was more consensual and less nationalistic. ${ }^{84}$ However, the choice might also be motivated by the fact that the church, the organization that administered the Quebec school system at the time, had favoured conscription. Thus, textbook authors, who were often clerics, had to conform to the church's vision in order to obtain its seal of approval.

Conscription is a topic addressed in the majority of Ontario textbooks; however, few display images to accompany the text. W.M. Stewart Wallace does not include it in his textbook, but both George Brown and Duncan McArthur include several pages regarding the controversies surrounding conscription, noting that the conscription issue split the Liberal party. Both textbooks blame Borden and Laurier for allowing the issue to divide the country. The largest discussion, five pages, takes place in the Lower and Chafe textbook, which also includes a large map of Canada featuring English- and French-speaking regions. This map, with shaded areas focused on the southern border regions of the country, is placed within a larger discussion about the French-English divide, and suggests a view of French Canadians as "others." Lower and Chafe provide their analysis, attempting to explain the different attitudes towards the war. They state that "English Canadians threw themselves into the war with unbounded energy, most of them feeling it was as much their responsibility as it was Great Britain's." 85 The text then adds that "French Canadians entered the war with some hesitation. France was no longer their Mother country and England could not be their Mother country by blood." This is followed by a statement that might explain the map: "The French-Canadian attitude toward European wars has been just about the same as that of the Americans; that is, both have wished as great a degree of neutrality as possible." 86 The text refers to "the horizons of French Canada being limited almost completely to the environment in which the race grew up; that of the lower St. Lawrence valley," and acknowledges the power of the curés to influence French families against participating in the war. It argues that the French Canadian population was mostly rural, and thus only "dimly understood what was going on beyond [their] own parish." ${ }^{87}$ The section ends with a further discussion of conscription and, after this strong diatribe, suggests that Canadians "not take sides in this house divided," despite the fact that the relationship between English and French Canadian has "never been one happy family." The authors suggest that students of history regard themselves as "one Canadian family." The image, however, does not suggest unity, since it reinforces the divisions between French- and English-speaking Canadians. $^{88}$

\section{Towards a Nation-Building Narrative}

Lastly, the theme of nation-building is present in all textbooks. Since Quebec history textbooks written between 1920 and 1948 were a product of the Catholic church, it is not surprising that the main views expressed in the narratives are similar to those held by the federal government; for the church had earlier on partnered with Ottawa. Moreover, the chosen narrative underlined church-approved values, such as courage, 
order, and unity. ${ }^{89}$ However, it seems that the church was also trying to find a place for French Canadians in the narrative without fostering too much nationalistic sentiment. This is clearly seen both in the choice of battles mentioned, such as those that took place at Courcelette and St-Éloi, where the 22nd battalion distinguished itself, and through the events and historical figures that are absent from the text. The absence of Henri Bourassa, for example, and of war heroes such as Tremblay or Brillant, and the important role taken by Laurier in the text, seems to point to the church's desire to foster a feeling of unity between French Canadians and the rest of Canada. However, the conscription crisis as well as the way it was covered in English newspapers represented opposition to the desire of the church for unity. This desire to find a place for French Canada in the narrative is also made clear in the choice of images found in the textbooks, where French Canadians or French Canadian symbols dominate, compared to English-Canadian and British iconography. Because of this, we believe that the church wanted French Canadians to feel that they had played an important role in this very positive, nation-building story, even though they had disagreed on conscription. ${ }^{90}$ Textbook authors might have wanted to find a place for French Canadians, not necessarily in opposition to the English position in the country, but rather as members of the winning team. In Desrosiers and Bertrand's Histoire $d u$ Canada, the only image found is of the Canadians at Courcelette, a battle in which the 22nd battalion had participated. Farley and Lamarche's Histoire $d u$ Canada: Cours supérieur also mentions specific battles in which the $22 \mathrm{nd}$, "a battalion composed uniquely of French Canadians, had distinguished themselves." 1 Moreover, Desrosiers, in his Petite histoire du Canada, speaks almost exclusively of the 22nd battalion, including a full-page image of it in the trenches. ${ }^{92}$ It seems, therefore, that it is through the $22 \mathrm{nd}$ battalion that French Canadians were portrayed as active participants in the war effort and an important player in the victory that followed.

Our comparison of the two provinces shows, as Vance has argued, that English and French Canada did not agree on how to commemorate the First World War. As noted, both provinces have similar timeline patterns seen through the narratives that reflect the chronology of the war; major causes of the war, Canadians in battles, issues of conscription, and outcomes and commemoration of the war. In Quebec, there is the added focus on the death of Laurier. It could be argued that between 1920 and 1948, the narrative of the First World War was relatively similar in Ontario and Quebec, as Djebabla and Mesli have argued. ${ }^{93}$ Yet, if the narrative framework is relatively similar, the images found in the textbooks are not. The two common images in both provinces are representations of King George V and Robert Borden. If images of Borden are found within the section dedicated to the First World War in both provinces, the role of King George $\mathrm{V}$ in the conflict is different. In the Ontario textbooks, the representation of the king is usually found at the very beginning of the majority of books, except in Duncan McArthur's text, where the king appears on the first page of the war chapter. However, in the Farley and Lamarche textbook - the only Quebec textbook to illustrate the monarch - the image of the king is found beside the section dealing with the causes of the war. It is as if, in Ontario, the king oversees the entire textbook, while in Quebec, the king seems to be one of the causes 
of the war, for the text notes that if Britain could not impose the war on Canada, the Dominion felt that it was its duty to participate. Thus, Ontario's textbooks seem to suggest that Canada entered the war for the Empire and came away more secure with its nationhood, while Quebec's textbooks seem to suggest Canada entered the war because of the Empire, but came away a more independent nation.

\section{How to Commemorate the War According to Textbooks}

The immediate post-war period in Canada saw Canadians trying to justify the impact of the war. As Jonathan Vance argues, the memorials of the 1920s and 1930s saw the "language of commemoration" dominated by the Winged Victory and the Rejoicing Soldier, symbols of earthly triumph and victory over death, and which were supported by so many of the narratives and images found in the history textbooks read by students in both provinces. ${ }^{94}$ In Quebec, Desrosiers' narrative in his Petite histoire du Canada is centred on the actions of the $22 \mathrm{nd}$ battalion and it quite understandable to see illustrated images of the arms of the Van Doos, a beaver with the motto "je me souviens" underneath it. In Ontario textbooks, it is the photograph of the National War Memorial Chamber in Ottawa. The image of the memorial is to ensure that schoolchildren commemorate the Canadians who served during the First World War. ${ }^{95}$ In Lower and Chafe's textbook, the memorial is surrounded by text that explores the impact of the Imperial War conference in 1917 and the "newly formed" Imperial War Cabinet. It argues that "out of the conference, came new relations [between] Great Britain and her dominions." 96

The textbooks in both provinces propose a common commemorative narrative that makes clear to students who the enemy was, the reasons why Canada became involved in the war, the role of French Canadians, the actions of Canadians to support the war, and the positive consequences of the conflict for the country. Although similar narratives appear in the texts, the images tell a different story. Ontario texts contain images of Byng or Currie, but in Quebec, the presence of Maréchal Foch is not merely a coincidence, but a clear choice. The authors seem to be claiming a place for French Canadians in an overall English-Canadian narrative that avoids a nationalistic stance that would counter the views of the Catholic church. Foch is an example of French courage, faith, and patriotism, a striking example of the type of citizen the Catholic church supported and wanted commemorated. ${ }^{97}$ It could be argued that if Keeland is right in supposing that French Canadians chose to remember the war by forgetting who supported it, such as General Tremblay, then the textbook authors might have chosen the French Maréchal, finding him closer to French-Canadian culture than Currie or any other English Canadian - but not too close as to foster nationalistic sentiment in students.

\section{Conclusion}

This article demonstrates the challenges each province faced in providing a history of the war to students in schools. The post-war period required Canadians to look 
back on the war and reflect on its effects. Textbooks played a part in providing narratives and images that helped students make some sense of the horrific conflict that took thousands of lives and left the country divided. The Ontario and Quebec textbooks from the post-war period reveal a number of mixed messages about the war, often evident in the careful placement of the illustrations within the text narratives. But what is common to history textbooks from both provinces is a country crafting narratives and images to commemorate the war in a positive light for its young citizens.

\section{Endnotes}

1 Joan Beaumont, "The Politics of Memory: Commemorating the Centenary of the First World War," Australian Journal of Political Science 50, no. 3 (2015): 529-535.

2 Ibid., 530.

3 See warmuseum.ca.

4 Desmond Morton, A Military History of Canada, 5th ed. (Toronto: McClelland \& Stewart, 2007); Jonathan Vance, Death So Noble: Memory, Meaning and the First World War (Vancouver: UBC Press, 1997); Margaret MacMillan, The War that Ended Peace: The Road to 1914 (Toronto: Penguin Canada, 2013); Jean-Pierre Gagnon, Le 22e Bataillon (canadien-français), 1914-1919: Étude socio-militaire (Québec: Presses de l'Université Laval, 1986); Tim Cook, Vimy:The Battle and the Legend (Toronto: Allen Lane Canada, 2017); Mourad Djebabla-Brun, Combattre avec les vivres: l'effort de guerre alimentaire canadien en 1914-1918 (Québec: Septentrion, 2015); Ian McKay and Jamie Swift, The Vimy Trap or, How we Learned to Stop Worrying and Love the Great War (Toronto: Between the Lines, 2016); James Wood, Militia Myths: Ideas of the Canadian Citizen Soldier, 1896-1921 (Vancouver: UBC Press, 2010).

5 Canadian Historical Review 95, no. 1 (March 2014); Canadian Historical Review 95, no. 3 (September 2014); Bulletin d'histoire politique 17, no. 2 (2009).

6 Vance, Death So Noble, 9.

7 Ibid., 10.

8 Duncan McArthur, History of Canada for High Schools (Toronto: W. J. Gage, 1927), 474.

9 Pearl James, ed., Picture This: World War 1 Posters and Visual Culture (Lincoln, NE: University of Nebraska Press, 2009), 2-5.

10 Penney Clark, "Images of Aboriginal People in British Columbia Canadian History Textbooks," Canadian Issues 4 (2016): 47-51.

11 George S. Tomkins, A Common Countenance: Stability and Change in the Canadian Curriculum, 2nd ed. (Vancouver: Pacific Educational Press, 2008), 145.

12 See David Freedberg, The Power of Images: Studies in the History and Theory of Response (Chicago: University of Chicago Press, 1989); William Gaudelli, "Interpreting Democratic Images: Secondary Students' Reading of Visual Texts," Teacher Education Quarterly 36, no. 1 (2009); Walter Werner, "Reading Visual Texts," Theory and Research in Social Education 30, no. 3 (2002): 401-428; Penney Clark, " 'Reckless Extravagance and Utter Incompetence': George Ross and the Toronto Textbook Ring, 1883-1907," Papers of the Bibliographical Society of Canada 46, no. 2 (2008): 185-235; Avril Maddrell, "Discourses of Race and Gender and the Comparative Method in Geography School Texts, 1830-1918," Environment and Planning D: Society and Space 16 (1998): 81-103.

13 Maddrell, "Discourses of Race and Gender and the Comparative Method." 
14 Werner, "Reading Visual Texts," 401.

15 Douglas Kellner, "Film, Politics, and Ideology: Reflections on Hollywood Film in the Age of Reagan," Velvet Light Trap (1991): 9.

16 Marie-Claude Larouche, "Voir et savoir interpréter des documents iconographiques de l'affectif au cognitif," in Faire aimer et apprendre l'histoire et la géographie, ed. MarcAndré Ethier, David Lafrançois, and Stéphanie Demers (Montréal: Multimonde, 2014), 222-223.

17 Eugene F. Provenzo, Jr., "Education and the Iconography of the Republic: Patriotic Symbolism in the Frontispieces of the Eighteenth- and Nineteenth-Century American Textbooks," in The Textbook as Discourse: Sociocultural Dimensions of American Schoolbooks, ed. Eugene F. Provenzo, Jr., Annis N. Shaver, and Manuel Bello (New York: Routledge, 2011), 32.

18 See Penney Clark, ed., New Possibilities for the Past (Vancouver: UBC Press, 2011); Peter Stearns, Peter Seixas, and Sam Wineburg, ed., Knowing, Teaching, and Learning History: National and International Perspectives (New York: New York University Press, 2000).

19 Ken Osborne, "Teaching Canadian History: A Decade of Debate," in Clark, New Possibilities for the Past, 58.

20 James, Picture This, 10.

21 Jay Winter, "Imaginings of War: Posters and the Shadows of the Lost Generation," in Picture This: World War 1 Posters and Visual Culture, ed. Pearl James (Lincoln, NE: University of Nebraska Press, 2009), 37.

22 Ibid., 46.

23 Illustrated War News, April 14, 1915.

24 Vance, Death So Noble, 23.

25 Wood, Militia Myths.

26 As explained by Gossage and Little, if conscription was widely accepted by English Canadians, the vast majority of French Canadians, led by the journalist and politician Henri Bourassa (1868-1952), were opposed to the project. Following the federal election of December 1917, which left Parliament divided between Borden's majority and Laurier's French-Canadian minority, Quebec City was the scene of riots and violence that took place in the spring of 1918 . The conscription crisis and the First World War in general are seen as an important event in Quebec's mounting nationalism. Peter Gossage and J. I. Little, Une histoire du Québec; Entre tradition et modernité (Montréal: Hurtubise, 2015), 227-230.

27 A. R. M. Lower and J. W. Chafe, Canada-A Nation: And How it Came To Be (Toronto: Longmans, Green, 1948), 428.

28 Abbé Adélard Desrosiers, Petite histoire du Canada (Québec: Librairie Garneau, 1933), 174.

29 Pearl James, Picture This, 2-5.

30 Tomkins, A Common Countenance, 215.

31 Ibid., 215-216. Also see Ontario Ministry of Education, A Brief History of Public and High School Textbooks Authorized for the Province of Ontario, 1849-1889 (Toronto: Author, 1890).

32 Richard Leclerc, L'histoire de l'éducation au Québec (Sillery: n.p., 1989), 65, http://collections.banq.qc.ca/ark:/52327/bs2106902.

33 Ibid., 65.

34 Clark, “'Reckless Extravagance and Utter Incompetence.' ”

35 Ibid., 51.

36 See Penney Clark, " "Liberty of Trade from the Thraldom of the Autocrats': Provision of School Textbooks in Ontario, 1850-1909," Canadian Journal of Education 29, 4 (2006): 1065-1096; and Clark, “'Reckless Extravagance and Utter Incompetence.' ” 
37 François Landry, Beauchemin et l'édition au Québec: Une culture modèle, 1840-1940 (Montreal: Fides, 1997).

38 George L. Parker, "Distributors, Agents, and Publishers. Part II: The Toronto Publishing Scene during World War I," Papers of the Bibliographical Society of Canada 44, no. 1 (2006): 6.

39 Marcel Trudel and Geneviève Jain, Canadian History Textbooks: A Comparative Study. Royal Commission on Bilingualism and Biculturalism. Studies, 5 (Ottawa: Queen's Printer, 1970). See also Jocelyn Létourneau, "Remembering Our Past: An Examination of the Historical Memory of Young Québécois, " in To the Past: History Education, Public Memory, and Citizenship in Canada, ed. Ruth Sandwell (Toronto: University of Toronto Press, 2006).

40 Ontario Ministry of Education, Curriculum Division, Circular 14 lists. See archives. org.

41 Robert Stamp, “Canadian High Schools in the 1920's and 1930's: The Social Challenge to the Academic Tradition," Canadian Historical Association 13, no. 7 (1978): 76-93. See also Robert Stamp, The Schools of Ontario, 1876-1976 (Toronto: University of Toronto Press, 1982).

42 Stamp, "Canadian High Schools," 77.

43 Tomkins, A Common Countenance, 206.

44 Félix Bouvier, Michel Allard, Paul Aubin, and Marie-Claude Larouche, L'histoire nationale à l'école québécoise; Regards sur deux siècles d'enseignement (Montréal: Septentrion, 2012).

45 Georges Croteau, Les frères éducateurs, 1920-1965. Promotion des études supérieures. Modernisation de l'enseignement public (Montreal: Hurtubise, 1996).

46 Béatrice Richard, "Le 1er avril 1918 -Émeute à Québec contre la conscription: résistance politique ou culturelle?" (Paper presented January 31, 2013, Conférence de Béatrice Richard, Foundation Lionel Groulx), http://www.fondationlionelgroulx. org/Le-1er-avril-1918-Emeute-a-Quebec.html, accessed September 10, 2017; René Durocher, "Henri Bourassa, les évêques et la guerre de 1914-1918," Historical Papers/ Communications historiques 6, no. 1 (1971): 248-275.

47 Richard, "Le 1er avril 1918."

48 Mourad Djebabla and Samy Mesli, "L'étude de la Première Guerre mondiale dans les manuels scolaires ontariens et québécois de l'entre-deux-guerres (1919-1939)," Bulletin d'histoire politique 17, no. 2 (2009): 125-140.

49 Stamp, The Schools of Ontario, 94.

50 Parker, "Distributors, Agents, and Publishers," 20; Nelson advertised "The Children's Story of the War," a weekly sixteen-page pamphlet by Sir Edward Parrott used in public schools.

51 Claudius Corneloup, L'épopée du vingt-deuxième Canadien-français (Montréal: La Presse, 1919).

52 Paul-Émile Farley and Gustave Lamarche, Questionnaire d'histoire du Canada (Montreal: Les Clercs de St-Viateur, 1930, 1937, 1945), 430.

53 Corneloup, L'épopée du vingt-deuxième.

54 Geoff Keeland, "'Il a bien mérité de la patrie': The 22nd Battalion and the Memory of Courcelette," Canadian Military History 19, no. 3 (2010): 4.

55 Ibid., 4.

56 Djebabla and Mesli, "L'étude de la Première Guerre."

57 Vance, Death So Noble, 259. Also cited in Keeland "Il a bien," 4.

58 George M. Wrong, Ontario Public School History of Canada (Toronto: Ryerson Press, 1921, 1924), 353.

59 W. L. Grant, Ontario High School History of Canada, 1922-1926 (Toronto: Ryerson Press, 1914, 1922), 408. 
60 Tim Cook, Vimy, the Battle and the Legend (Toronto: Allan Lane, 2017), 346.

61 See Tim Cook, The Madman and the Butcher (Toronto: Allen Lane, 2010).

62 Author interview with Tim Cook, Canadian History of Education Association, Waterloo, Ontario, Fall 2016.

63 Desmond Morton, Canada and War: A Military and Political History (Toronto: Butterworths, 1981), 65.

64 See also Laura Brandon, "Words and Pictures: Writing Atrocity into Canada's First World War Official Photographs," Journal of Canadian Art History 31, no. 2 (2010): 110-126.

65 Helen B. McCartney, "The First World War Soldier and His Contemporary Image in Britain," International Affairs 90, no. 2 (2014): 299-315.

66 Desrosiers, Petite histoire, 528.

67 Abbé Adélard Desrosiers and Camille Bertrand, Histoire du Canada (Montréal: Beauchemin Éditeur, 1923, 1925, 1933), 452.

68 Eric Labayle, "La bataille de Vimy: de l'Histoire à la mémoire," Bulletin d'histoire politique 17, no. 2 (2009): 157.

69 Lower and Chafe, Canada - A Nation, 420.

70 W.M. Stewart Wallace, A History of the Canadian People (Toronto: Copp Clark, 1930), 325-327.

71 Ibid., 327.

72 Ibid., 328.

73 W. L. Grant, The Ontario High School History of Canada (Toronto: Ryerson Press, 1922), 372.

74 Ibid., 379.

75 Ibid.

76 George Brown, Building the Canadian Nation (Toronto: J. M. Dent, 1942), 502.

77 Robert Price, "The Mythology of War: How the Canadian Daily Newspaper Depicted the Great War" (PhD diss., University of Toronto, 1998).

78 See Brock Millman, Polarity, Patriotism and Dissent in Great War Canada, 1914-1919 (Toronto: University of Toronto Press, 2016); Lara Campbell, Michael Dawson, and Catherine Gidney, eds., Worth Fighting For (Toronto: Between the Lines, 2015).

79 Lower and Chafe, Canada-A Nation, 423.

80 Ibid., 419.

81 Morton, Canada and War, 71.

82 Durocher, "Henri Bourassa."

83 Refer to note 25, and Gossage and Little, Une histoire du Québec, 227-230.

84 Djebabla and Mesli, "L'étude de la Première Guerre," 137-138.

85 Lower and Chafe, Canada-A Nation, 423.

86 Ibid., 423-424.

87 Ibid., 422-427.

88 Ibid.

89 Richard, "Le 1er avril 1918."

90 See Robert Price and http://www.collectionscanada.gc.ca.

91 Paul-Émile Farley and Gustave Lamarche, Histoire du Canada; cours supérieur (Quebec: Librairie de Clercs de St-Viateur), 428.

92 Desrosiers, Petite histoire, 173.

93 Djebabla and Mesli, "L'étude de la Première Guerre."

94 Vance, Death So Noble, 17.

95 See http://www.veterans.gc.ca/eng/remembrance/history/first-world-war/canada/ canada20.

96 Lower and Chafe, Canada - A Nation, 428.

97 Keeland, "Il a bien," 3-4. 


\section{Appendix I \\ Ontario Textbooks Analyzed for this Paper (in order of date published)}

1. George M. Wrong. Ontario Public School History of Canada. Toronto: Ryerson Press, 1921, 1924.

2. W. L. Grant. The Ontario High School History of Canada. Toronto: Ryerson Press, 1914, 1922.

3. Duncan McArthur. History of Canada for High Schools. Toronto: W. J. Gage, 1927.

4. W.M. Stewart Wallace. A History of the Canadian People. Toronto: Copp, Clark, 1930.

5. George Brown. Building the Canadian Nation. Toronto: J. M. Dent, 1942, 1946.

6. A. R. M. Lower and J. W. Chafe. Canada - A Nation: And How It Came To Be. Toronto: Longmans, Green, 1948.

\section{Appendix II \\ Quebec Textbooks Analyzed for this Paper (in order of date published)}

1. Les Frères du Sacré-Coeur. L'histoire du Canada. Arthabaska: Eug. Norman Imprimeur, 1920.

2. Les Frères du Sacré-Coeur. Chronologie de l'histoire du Canada. Montréal: N.p., 1922, $1933,1938$.

3. L'Abbé Adélard Desrosiers and Camille Bertrand. Histoire du Canada. Montréal: Beauchemin Éditeur, 1923, 1925, 1933.

4. Joseph Rutché and Anastase Forget. Précis d'histoire du Canada; pour les élèves des classes supérieures de l'enseignement secondaire. Montréal: Beauchemin, 1924, 1928, 1932, 1937, 1945.

5. Eugène Archand. Histoire générale de l'église d'après le nouveau programme. Montréal: Beauchemin, 1927, 1929.

6. Paul-Émile Farley and Gustave Larmarche. Questionnaire d'histoire du Canada. Montreal: Les Clercs de St-Viateur, 1930, 1937, 1945.

7. L’abbé L.-N. Bégin. Chronologie de l'histoire du Canada. Québec: N.p., 1931, 1939.

8. Paul-Émile Farley and Gustave Lamarche. Histoire du Canada; cours supérieur. Québec: Librairie des Clercs de St-Viateur, 1933.

9. L'Abbé Adélard Desrosiers. Petite histoire du Canada. Québec: Librairie Garneau, 1933.

10. Cahiers Pédagogique. Histoire générale; Époque contemporaine. Granby: La voix du Mont-Sacré-cœur, 1943.

11. Les Frères des Écoles Chrétiennes. Histoire du Canada. Montréal: Les Frères des Écoles Chrétiennes, 1947. 